\title{
Analysis of interaction of the soil temperature field and structures at the level of the basement of the building
}

\author{
Petr Kacálek ${ }^{1, *}$, and Tomáš Petř́íck ${ }^{1}$ \\ ${ }^{1}$ Brno University of Technology, Faculty of Civil Engineering, Institute of Building Structures, \\ Veveří 95, 60200 Brno, Czech Republic
}

\begin{abstract}
The article describes an analysis of the effect of soil type on temperature field distribution at the level of family house basement. Regarding engineering calculations (heat loss calculation, designing and evaluating constructions), a simple and generally accepted method to determine the course of temperature field adjacent to basement walls is missing. The methods specified in European standards are, in terms of calculation of heat flows in soil, problematic. There is currently an insufficient number of measured values, which could be integrated in a simple calculation method. A certain option concerns continual measuring of temperatures in soil for buildings in situ. The article uses the measurements of soil temperatures in winter in pre-determined depths at the building parts in contact with soil. The measured data from a two-year period were integrated in the model on the basis of statistical evaluation. The main aim of the article is to generate an impulse to create unified outcomes of temperatures of certain soils for pre-selected depths, building structures, and parameters of indoor and outdoor environment.
\end{abstract}

\section{Introduction}

The distribution of temperatures in soil under buildings is currently relatively little examined field of civil engineering physics, even though it is closely related to accurate calculations of heat technology.

Despite being different from air temperature, soil temperature reflects long-term trends in air temperature, and the temperature differences on the surface are then transferred deeper. Soil has relatively low heat conductivity, reacts slower to climatic conditions, and its underground reaction to changes in external effects is also slow. The temperature of soil is different from air temperature; in most cases the soil temperature is higher, and their difference then depends on precipitation conditions, snow cover, vegetation type and changes over time, soil quality, heat accumulation, etc.

Other factors that affect soil temperatures include well designed surrounding building structures. They particularly concern correctly selected heat insulation, waterproofing [1]

\footnotetext{
* Corresponding author: kacalek.p@,fce.vutbr.cz
} 
(locally much used bituminous sheets), and in many cases well designed details (at the level of building entrances [2], well made waterproofing joints [3], etc.).

The faults in waterproofing have negative effect on heat conductivity coefficient of selected material; subsequently, the heat conductivity coefficient fails to meet the selected standard requirements of the designed construction material. Building constructions must be repaired (using direct or indirect methods) and the whole process results in changes in the temperature field of the evaluated structure [4].

The distribution of temperatures in soil in civil engineering is particularly used for a calculation of specific heat flux of buildings with and without cellar.

\section{Options for modelling of soil temperatures at buildings}

The real measuring of soil temperature of buildings is a not an easy task. Such measurement can generally be performed only with devices that allow recording of temperatures in certain depths. However, this is not always the case and, therefore, in the majority of cases we need to make an estimate of how high the temperatures in soil at a building can be.

The designed soil temperatures, or estimates of soil temperatures in ${ }^{\circ} \mathrm{C}$, adjacent to vertical or horizontal building structures in winter are shown in Table 1.

Table 1. Designed soil temperature in winter, adjacent to building structures according to ČSN 73 0540-3 [5].

\begin{tabular}{|c|c|c|c|}
\hline \multirow{2}{*}{ Location of adjacent soil layer } & \multicolumn{2}{|c|}{$\begin{array}{c}\text { Temperature of adjacent soil in }{ }^{\circ} \mathrm{C} \text { at designed ambient } \\
\text { air temperature }\end{array}$} \\
\cline { 2 - 4 } & $\theta_{\mathrm{e}}>-15^{\circ} \mathrm{C}$ & $\theta_{\mathrm{e}} \leq-15^{\circ} \mathrm{C}$ \\
\hline \multirow{2}{*}{$\bar{C}$} & up to depth of $1 \mathrm{~m}$ & -3 & -6 \\
\cline { 2 - 4 } & in depth of 1 to $2 \mathrm{~m}$ & 0 & -3 \\
\cline { 2 - 4 } & in depth of 2 to $3 \mathrm{~m}$ & +3 & 0 \\
\hline
\end{tabular}

The estimates of temperatures for structures adjacent to soils are allowed according to the existing valid standard ČSN 73 0540, particularly regarding the calculation of specific heat flux $\mathrm{H}_{\mathrm{T}}$ (estimate of temperature is a part of temperature reduction coefficient $b$ for structures in contact with soil).

Variant estimate of temperatures of soil under buildings is also provided by standard ČSN EN ISO 10211-1 Thermal bridges in building construction - General calculation methods [6].

This article describes the issue of temperature field of soils around basement part of a building. The main aim of the article focuses on extending the knowledge in this issue.

The practice part (Fig. 1) consists of measurements of a real building in $2007-2009$. Based on the statistically evaluated data and existing legislation, a theoretical simulation in Ansys software was made which simulates the real measurement at the building. As a part of the simulation, the trend in temperatures at the interface of soil and building structures is shown together with the application of different boundary conditions.

\section{Experimental measurement}

The experimental measurement was performed for a real family house construction (hollow core bricks CD INA-A, pre-wall CPP). The construction is on the northeast side, along the 
whole length, partially under the terrain; there is a downslope towards the west. The surroundings include a rolling terrain, the lowest point is $328 \mathrm{~m}$ above sea level, and the highest point of the locality is $524 \mathrm{~m}$ above sea level.

The following values were monitored during the experimental measurement on the real structure (internal air temperature, relative humidity of internal air, external air temperature, relative humidity of external air, height of snow cover, soil temperature in pre-selected depths, soil heat conductivity coefficient, pre-wall heat conductivity coefficient, external walls heat conductivity coefficient). [7]

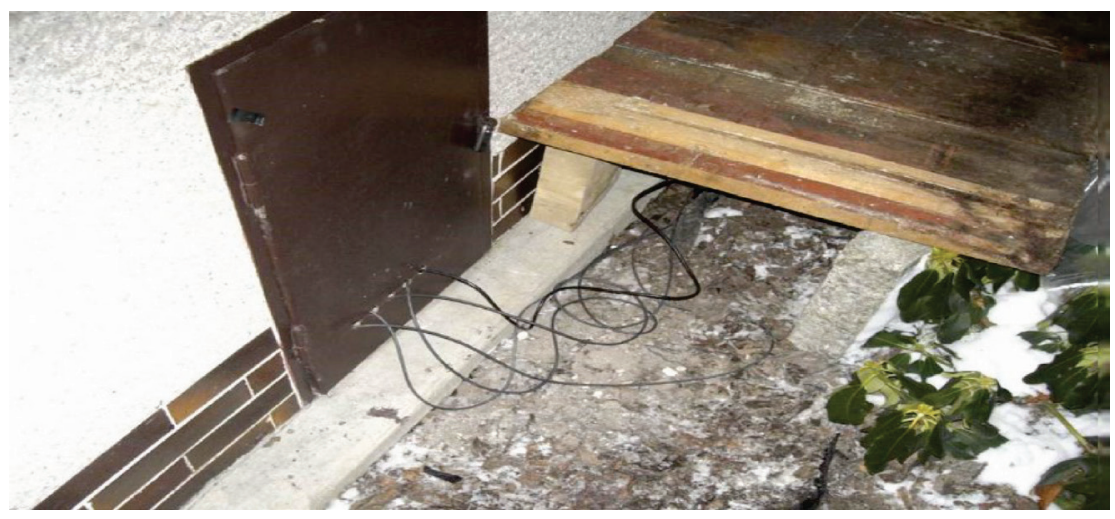

Fig. 1. View of probes placed in soil at family house structure.

\section{Measurement and evaluation of measured values}

Values were recorded continuously without interruption for two years. The device recorded temperatures every 15 minutes. The setting of this time interval gives us sufficient overview of individual temperatures. In order to provide clearer overview of statistical files, individual boundary conditions are represented by temperature median values. The external and internal environment will be characterized by the median values of external air temperature $+2.1{ }^{\circ} \mathrm{C}$ and median values of internal air temperature $+11{ }^{\circ} \mathrm{C}$ shown in Table 2 .

Table 2. Soil temperatures (sandy clay) [7].

\begin{tabular}{|c|c|c|c|}
\hline & \multicolumn{3}{|c|}{ Median values of external air temperature $+2.1^{\circ} \mathrm{C}$} \\
\hline & $\begin{array}{l}\text { Depth of measurement } \\
(\mathrm{m})\end{array}$ & $\begin{array}{c}\text { Arithmetic average } \\
\left({ }^{\circ} \mathrm{C}\right)\end{array}$ & $\begin{array}{c}\text { Temperature median } \\
\left({ }^{\circ} \mathrm{C}\right)\end{array}$ \\
\hline \multirow{4}{*}{$\begin{array}{l}\text { Median value of } \\
\text { internal air } \\
\text { temperature } \\
+\mathbf{1 1 . 0}^{\circ} \mathrm{C}\end{array}$} & 0.40 & 7.53 & 7.90 \\
\hline & 0.80 & 9.29 & 9.30 \\
\hline & 1.20 & 9.45 & 9.70 \\
\hline & 1.50 & 10.71 & 10.60 \\
\hline
\end{tabular}

\section{Model of temperature field of foundation soil based on measurements at real structure}

If we are interested in temperatures on building structures in contact with soil, it is necessary to take into account effects of more-dimensional heat conductivity in soil under the structure. In that case we need to create a model and determine the temperature 
distribution by numeric solution of more-dimensional temperature field by the network method or finite elements method. [7]

The simulation model shown in Fig. 2 is based on the values measured during an in-situ survey of the building. The modelling considered all values as isotropic material.

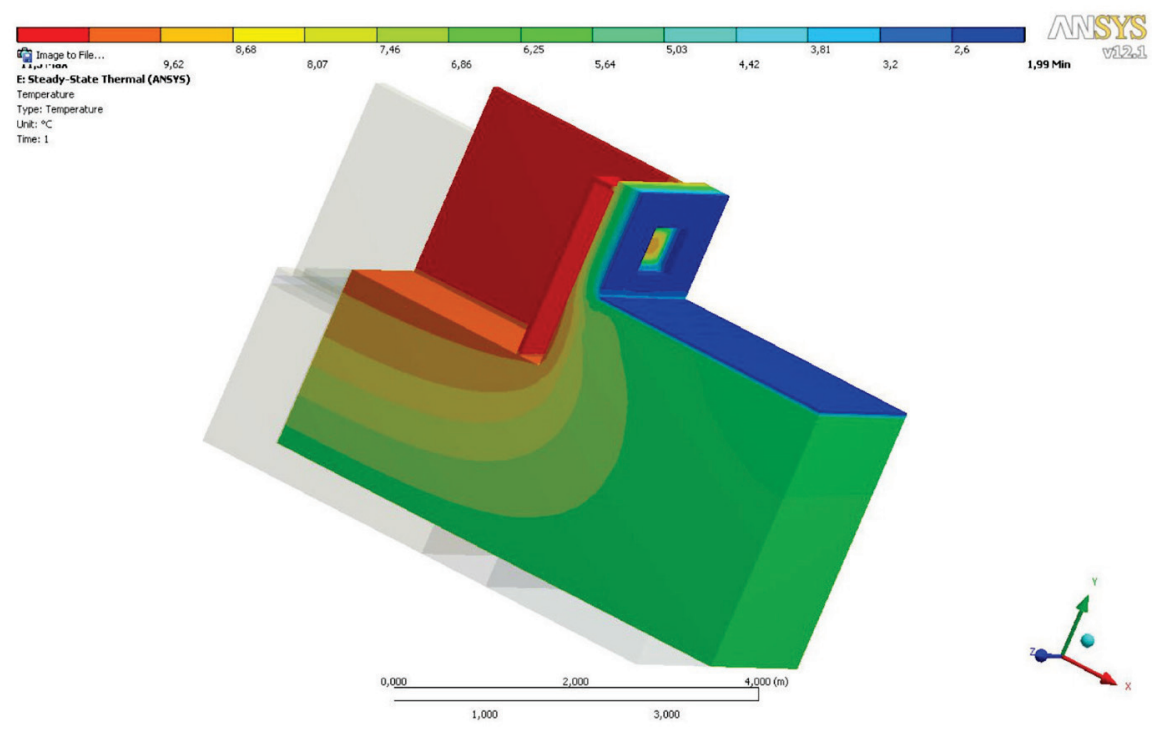

Fig. 2: Model of a part of structure.

\section{Influence of indoor air temperature changes on temperature field in the basement structures}

The simulation takes into account the design standard temperatures of internal as well as external air while using the model from the measuring and modelling of the real structure.

External environment will be characterized by a temperature field with design temperature of $-15^{\circ} \mathrm{C}$, design internal temperature for winter environment of $+21^{\circ} \mathrm{C}$ and $+10{ }^{\circ} \mathrm{C}$.

Tables 3 and 4 show temperatures in selected depths for individual soil types.

Table 3. Design temperature of external air $-15^{\circ} \mathrm{C}$, design temperature of internal air $+10.0{ }^{\circ} \mathrm{C}$; $(*(\mathrm{~W} / \mathrm{m} . \mathrm{K}))$ - value in brackets for coefficient of heat penetration through given soil.

\begin{tabular}{|c|c|c|c|c|c|}
\hline \multirow{4}{*}{} & \multicolumn{5}{|c|}{ Design temperature of external air $-\mathbf{1 5}^{\circ} \mathbf{C}$} \\
\cline { 2 - 6 } & $\begin{array}{c}\text { Measurement } \\
\text { depth }\end{array}$ & $\begin{array}{c}\text { Sandy clay } \\
(\mathbf{2 . 7 6 ;} \mathbf{1 . 6 8}) \\
\text { real model }\end{array}$ & $\begin{array}{c}\text { Soils and } \\
\text { clays }(1.5)\end{array}$ & $\begin{array}{c}\text { Dry sand } \\
(2.0)\end{array}$ & $\begin{array}{c}\text { Wet sand } \\
(2.7)\end{array}$ \\
\cline { 2 - 6 } & $(\mathrm{m})$ & $\left({ }^{\circ} \mathrm{C}\right)$ & $\left({ }^{\circ} \mathrm{C}\right)$ & $\left({ }^{\circ} \mathrm{C}\right)$ & $\left({ }^{\circ} \mathrm{C}\right)$ \\
\hline \multirow{3}{*}{$\begin{array}{c}\text { Design internal air } \\
\text { temperature } \\
+\mathbf{1 0 . 0}{ }^{\circ} \mathbf{C}\end{array}$} & 0.40 & $\mathbf{4 . 2 2}$ & 4.32 & 4.80 & 5.39 \\
\cline { 2 - 6 } & 0.80 & $\mathbf{6 . 0 7}$ & 6.12 & 6.42 & 6.08 \\
\cline { 2 - 6 } & 1.20 & $\mathbf{7 . 4 0}$ & 7.42 & 7.65 & 7.92 \\
\hline
\end{tabular}


Table 4. Design temperature of external air $-15{ }^{\circ} \mathrm{C}$, design temperature of internal air $+21.0{ }^{\circ} \mathrm{C}$; $(*(\mathrm{~W} / \mathrm{m} . \mathrm{K}))$ - value in brackets for coefficient of heat penetration through given soil.

\begin{tabular}{|c|c|c|c|c|c|}
\hline \multirow{4}{*}{} & \multicolumn{5}{|c|}{ Design temperature of external air $-\mathbf{1 5}^{\circ} \mathbf{C}$} \\
\cline { 2 - 6 } & $\begin{array}{c}\text { Measurement } \\
\text { depth }\end{array}$ & $\begin{array}{c}\text { Sandy clay } \\
(\mathbf{2 . 7 6 ;} \mathbf{1 . 6 8}) \\
\text { real model }\end{array}$ & $\begin{array}{c}\text { Soils and } \\
\text { clays }(1.5)\end{array}$ & $\begin{array}{c}\text { Dry sand } \\
(2.0)\end{array}$ & $\begin{array}{c}\text { Wet sand } \\
(2.7)\end{array}$ \\
\cline { 2 - 6 } & $(\mathrm{m})$ & $\left({ }^{\circ} \mathrm{C}\right)$ & $\left({ }^{\circ} \mathrm{C}\right)$ & $\left({ }^{\circ} \mathrm{C}\right)$ & $\left({ }^{\circ} \mathrm{C}\right)$ \\
\hline \multirow{3}{*}{$\begin{array}{c}\text { Design internal air } \\
\text { temperature } \\
+\mathbf{2 1 . 0}{ }^{\circ} \mathbf{C}\end{array}$} & 0.40 & $\mathbf{8 . 8 9}$ & 9.43 & 9.39 & 9.41 \\
\cline { 2 - 6 } & 0.80 & $\mathbf{1 0 . 8 5}$ & 11.19 & 10.91 & 10.70 \\
\cline { 2 - 6 } & 1.20 & $\mathbf{1 1 . 7 6}$ & 12.02 & 11.68 & 11.39 \\
\hline
\end{tabular}

\section{Conclusions}

The existing results of temperatures in soil at the structure show that the main effect on soil temperature is internal air temperature, where the underground building parts transfer substantial amount of heat to the soil. As mentioned above, the model and the simulation were based on a real building structure. It is necessary to bear in mind that the structures were not insulated and could not have been used as sufficient insulators. The influence of sufficient insulation in the interface structure - soil on soil temperature can be subjected to another experiment.

It is not currently apparent from the measurement what role is played by snow cover and vegetation in the resulting temperature. Good quality of the waterproofing layer of the substructure may have a substantial effect on the resulting temperatures $[1,3]$.

It is obvious from closer comparison of Tables 3 and 4 with Table 1 that the temperatures in the depth up to $1 \mathrm{~m}$ and temperatures from $1 \mathrm{~m}$ to $2 \mathrm{~m}$ differ significantly.

Experimental and theoretical simulations are used to offer us a better idea of soil temperatures around structures. After verifying the given measurement at other structures within several years, it is partially possible to make the existing values of adjacent soil temperatures more accurate.

This paper has been worked out under the project No. LO1408 "AdMaS UP - Advanced Materials, Structures and Technologies", supported by Ministry of Education, Youth and Sports under the „National Sustainability Programme I”.

\section{References}

1. J. Plachý, V. Petránek, Z. Caha, AMR 897, 103-106 (2014),

2. R. Smolka, J. Sobotka, J. Šulistová, MATEC Web of Conferences 93, 01009 (2017)

3. T. Petř́iček, P. Kacálek, T. Hlavačka, MATEC Web of Conferences 93, 03007 (2017)

4. J. Sobotka, R. Smolka, MATEC Web of Conferences 93, 01008 (2017)

5. CSN 73 0540-3 Thermal protection of buildings - Part 3: Design value quantities (Czech office for standards, metrology and testing, Prague, 2005)

6. CSN EN ISO 10211 (73 0551) Thermal bridges in building construction - Heat flows and surface temperatures - Detailed calculations (Czech office for standards, metrology and testing, Prague, 2009)

7. P. Kacálek, T. Petříček, R. Smolka, AMR 889, 58-61 (2014) 
